\title{
NUTM2B wt Allele
}

National Cancer Institute

\section{Source}

National Cancer Institute. NUTM2B wt Allele. NCI Thesaurus. Code C101102.

Human NUT M2B wild-type allele is located in the vicinity of 10q22.3 and is approximately $16 \mathrm{~kb}$ in length. This allele, which encodes NUT family member 2B protein, has no known function. A translocation $t(10 ; 17)(q 22-23 ; p 13)$ that fuses this gene with the YWHAE gene is associated with high-grade uterine endometrial stromal sarcoma. 